\title{
Turizm Yatırım Teşvikleri Çerçevesinde Antalya
}

Tourism Investment Incentives in Antalya

\author{
Eda Evla MUTLU*, Gözdegül BAŞER** \\ * (Sorumlu Yazar), Dr. Öğr. Üyesi, Antalya Bilim Üniversitesi, Turizm Fakültesi, Çıplaklı Mahallesi, Akdeniz Bulvarı, No: 290, PK 07190, Antalya. \\ E-posta: evla.mutlu@antalya.edu.tr, eevlamutlu@gmail.com \\ ORCID: 0000-0001-9940-570X \\ ** Dr. Öğr. Üyesi, Antalya Bilim Üniversitesi, Turizm Fakültesi, Çıplaklı Mahallesi, Akdeniz Bulvarı, No:290, PK 07190, Antalya. \\ E-posta:gozdegul.baser@antalya.edu.tr \\ ORCID: 0000-0002-1450-191X
}

MAKALE BILGILERI

Makale işlem bilgileri:

Gönderilme tarihi: 18 Ocak 2020

Düzeltme: 9 Haziran 2020

Kabul: 14 Haziran 2020

Anahtar sözcükler: Turizm yatırımları, Yatırım teşvik istatistikleri, Antalya.

\section{ARTICLE INFO}

Article history:

Submitted: 18 January 2020

Resubmitted: 9 June 2020

Accepted: 14 June 2020

Key words: Tourism investments, Investment incentive statistics, Antalya.

\begin{abstract}
$\ddot{O Z Z}$
Kamu yatııım teşvikleri, yatırım kararlarını yönlendiren, farklı bölgelere ve sektörlere verilebilen, çeșitli kapsamlardaki imtiyazlardır. Turizm alanında verilen desteklerden yüksek oranda yararlanan şehirlerden biri de turizm potansiyeli yüksek olan Antalya ilidir. Bölgedeki mevcut teşvik talebini anlamak ve geleceğe yönelik öngörü kazanabilmek adına, bu çalıșmada son bes yılda turizm alanında verilen yatırım teșvik listeleri incelenmiș ve konuyla ilgili görüșmeler yapılmıştır. Elde edilen veriye göre, Antalya'ya verilen turizm teşviklerinin yıllar içinde azaldığı, iptal edilen teşvikler açısından da Antalya'daki oranın diğer illerden daha yüksek olduğu anlaşılmıştır. Yapılan görüșmelerde teșvik başvurularının azalması, ișletmelere çeșitli avantajlar sağlayan kültür ve turizm koruma ve geliștirme bölgelerindeki doluluğun artması ile ilișkilendirilmiștir. Değișen turist profili de göz önünde bulundurularak, kitle turizminin dışında butik işletmeciliği de destekleyecek kapsamda bir teşvik planlamasına yönelik öneriler sunulmuştur. Bununla birlikte golf veya kırsal turizm gibi turizm türlerine odaklanan teşviklerin, potansiyeli yüksek ilçeler için arttırılmasının, bölgesel kalkınma açısından önemine değinilmiştir.
\end{abstract}

\begin{abstract}
Governmental investment incentives are concessions of various scopes, given to a variety of sectors or territories that direct the investment decisions. One of the cities that benefited greatly from the incentives given in the field of tourism is Antalya, which has a high tourism potential. In order to understand the current incentive demand in the region and gain insight into the future, this study examined the investment incentives given in the field of tourism in the last five years and interviewed related stakeholders. According to the data, it is recognized that the tourism incentives given to Antalya decreased over the years. Besides the rate of canceled incentives in Antalya is higher than the other provinces. As a result of interviews, decrease in demand has been associated with increased occupancy in cultural and tourism protection and development regions, which provide various investment advantages. Taking into consideration the changing tourist profile, suggestions were made for an incentive planning that would support boutique management besides mass tourism. However, the importance of increasing the incentives that focus on specific tourism types such as golf or rural tourism for the districts with high potential is emphasized for regional development.
\end{abstract}

\section{GiRiş}

Yatırım teşvikleri, kamu veya özel kurumlar veya şahıslar tarafından verilen, stratejik öneme sahip girişimleri destekleyici katkılar veya kolaylıklar olarak tanımlanabilir. Verilen teşviklerle kuramsal anlamda bölgeler arası ekonomik eşitsizliklerin azaltılması amaçlanabileceği gibi (Şahin ve Uysal 2011), yabancı sermayenin yurtiçi yatırımlarını arttırması, belirli alanlarda istihdamın art- tırılması veya sosyal yaşamın düzenlenmesi de (Yavan 2012) amaçlanabilmektedir. Bir anlamda kamu ve özel sektör arasındaki ilişkileri düzenleyen teşvikler, aynı zamanda pazardaki aksaklıkların giderilmesi için sosyo-politik bir araç görevi de görebilmektedir (Wanhill 2005). Özellikle gelişmekte olan ülkelerde devletin teşvikler yoluyla sektöre müdahalesi, yenilikçi ve güçlü şirketlerin olmayışı sebebiyle bir zorunluluk olarak ifade edilmektedir (Jenkins ve Henry 1982). 
Türkiye'de gelişmekte olan bir ülke olarak turizm sektörüne yönelik yatırım teşvikleri, turizmin gelişimi açısından kritik öneme sahiptir; ancak, konu ile ilgili çalışma sayısı kısıtlıdır. Mevcut çalışmalar süreçle ilgili önemli çıtıları ortaya koymakla birlikte (Bkz. Toker 2007), 1 Ocak 2012 tarihinden itibaren kullanılan yeni teşvik sistemini kapsamamaktadır. Güncel teşvik sistemini inceleyen çalışmalar ise (Özgen 2013; Dalgın, Karadağ ve Bingöl 2015; Şanlıŏlu ve Özcan 2017) erken dönem çalışmalar oldukları için teşvik verilerini kapsamlı olarak incelememiştir. Bu çalışmada ise Türkiye'deki yatırım teşvik sürecine kısaca değinildikten sonra, güncel teşvik sisteminin kapsamı açıklanmış, daha sonra son beş yılda belli başlı illere verilen teşvik istatistikleri incelenerek Antalya iline verilen teşvikler değerlendirilmiştir. Böylece güncel teşvik sistemi göz önünde bulundurularak, ilk defa Antalya iline verilen turizm teşviklerinin sektöre etkisini anlamaya yönelik bir akademik çalışma gerçekleştirilmiştir. Çalışma ayrıca teşviklerle ilgili iyileştirmeye açık alanları otaya koyarak, sektörel gelişim için önerilerde bulunmaktadır.

\section{ALANYAZIN}

Bu bölümde öncelikle yazındaki çalışmalardan, Türkiye'deki turizm teşviklerinin tarihi sürecine kısaca değinilmiştir. Bu sürecin neticesinde şekillenen günümüzdeki güncel teşvik sistemi tartışılmıştır. Son olarak da güncel teşvik sistemi içinde önemli ayrıcalıklar sağlayan geliştirme bölgeleri ve Antalya ilinin geliştirme bölgeleri açısından mevcut durumu anlatılmıştır.

\section{Turizm Teşviklerinin Gelişimi}

Teşviklerin odak noktası, döneme ve ihtiyaca göre şekillenebilmektedir. Örneğin Osmanlı döneminde Teşvik-i Sanayi Kanun-1 Muvakkatı ve ardından da Teşvik-i Sanayii Muvakkatı gibi yasal düzenlemelerle başlayan teşvikler, o dönemde doğrudan sanayinin gelişmesine odaklanmıştır (Kasalak 2012). Günümüzde ise Yatırım Ofisi (t.y.) bilgilendirmesine göre teşvikler; vergi indirimi, arsa tahsisi gibi kolaylaştırıcı unsurları içerebildiği gibi stratejik sektörler için ayrılan yatırım fonlarını da kapsamaktadır. 1 Ocak 2012 tarihinden itibaren geçerli olan "yeni yatırım teşvik sistemi" incelendiğinde (Yatırım Ofisi t.y.) teşvikler; bölgesel veya bölgeye bağlı olmaksızın stratejik sebeplerle verilebilen, sanayi yanında hizmet sektörünü de kapsayan bir dizi yasal düzenlemelerdir ${ }^{1}$.

Hizmet ağırlıklı turizm sektörü de kamu kurumlarının verdiği teşviklerden yararlanabilen alanlardan biridir². Turizmle doğrudan ilişkili teşvik düzenlemesi, 1950 yılında yürürlüğe giren Turizm Müesseselerini Teşvik Kanunu ile başlamış, 1953 yılında yayınlanan Turizm Endüstrisini Teşvik Kanunu ile devam etmiştir (Toker 2007; Andaç 2013). Sonrasında yaşanan gelişmeleri Şanlıoğlu ve Özcan (2017) şu şekilde sıralamaktadır; 1957'de Turizm Bankası'nın kurulmaSı, 1980 yılında Turizm Teşvik Çerçeve Kararı'nın alınması ve 1982 yılında 2634 sayılı Turizmi Teşvik Kanunu'nun (1982) yayınlanması. Ayrica turizm yatırımlarının, 1983'ten sonra dönemin Başbakan'ı Turgut Özal'ın yol, su, elektrik gibi altyapı iyileştirmeleri ve yatırımcılara arazi tahsis edilmesi gibi çalışmaları ile hız kazandığı ifade edilmektedir (Turizm ve Yatırım İşletme ve Endüstri Dergisi 2012: 6; Yücel 2012). 1980-1997 yılları arasında, sağlanan teşviklerin etkisiyle döviz gelirleri, tesis ve oda sayılarında artış gözlenmiştir (Şanlıoğlu ve Özcan 2017). 1982 yılında kabul edilen 2634 sayılı Turizmi Teşvik Kanunu hala yürürlüktedir ve Bakanlık tarafından verilen teşvikler bu kanun çerçevesinde düzenlenmektedir.

Türkiye Cumhuriyeti Cumhurbaşkanlığ 1 Strateji ve Bütçe Başkanlığ 1 (2019) tarafından yayınlanan 2019-2023 On Birinci Kalkınma Planı'nda turizm, öncelikli gelişme alanlarından biri olarak kabul edilmektedir. Plan kapsamında Türkiye Turizm Tanıtım ve Geliştirme Ajansı'nın kurulması, farklı turizm türlerine yönelim için altyapı

\footnotetext{
${ }^{1}$ Bu bilgiye T.C. Cumhurbaşkanlığı Yatırım Ofisi resmî web sitesi olan $h t t p: / / v 1$.invest.gov.tr/ adresi üzerinden erişilmiştir. Bu çalışma devam ederken Yatırım Ofisi https://wwww.invest. gov.tr/ sitesinin Beta sürümünü yayınlamıştır. Beta sürümünde, okuyucu v1.invest.gov.tr adresine ulaşamadığında invest. gov.tr adresinden teşviklerle ilgili bilgiye erişebilir.

${ }^{2}$ Çalışma boyunca tekrar eden yatırım teşvikleri, kamu tarafından verilen yatırım teşvikleridir.
} 
iyileştirmeleri gibi hedefler üzerinde durulmuştur. Dolayısıyla turizm alanı, önümüzdeki yıllarda da kalkınma açısından önemli iş kollarından biri olmaya ve muhtemelen çeşitli yatırım teşvikleri ile gelişmeye devam edecektir.

Yazında teşviklerin hangi alanlarda verilmesi ve bu ayrıcalıkların sağladığı finansal yarara yönelik çeşitli görüşler bulunmaktadır (Bodlender 1982; Jenkins 1982; Wanhill 1986). Günümüze ihracat ağırlıklı ve döviz kazandıran hizmetlere yönelik turizm desteklerinin yanı sıra, yatırım ve istihdam destekleri, sektöre hizmet veren $\mathrm{KO}$ BI'lere yönelik ayrıcalıklar gibi geniş bir yatırım teşvik çeşitliliğinden bahsedilebilir (Andaç 2013). Girişimcilerin iş kurma sürecinde KOSGEB'den almış olduğu finansal ve finansal olmayan desteklerle, bir otelin oda sayısını arttırmak için yapacağ 1 iyileştirme yatırımına aldığ yatırım teşviki olarak düşünülebilir. Bu desteklerin içinde doğrudan yabancı sermaye yatırımlarının turizm sektörüne etkisi (Bahar 2010), teşviklerin hangi unsurlara göre dağıtıldığ 1 (Yavan 2012) gibi farklı konular akademik alanda çalışılmıştır. Bununla birlikte kamu araçlarının ekonomik anlamda az gelişmiş bölgelerin gelişimine yönelik politikalar üreterek dengeleme gayretlerinin, yetersiz ve başarısız olduğu vakalara da rastlanmaktadır (Oduro-Ofori 2011).

\section{Güncel Yatırım Teşvik Sistemi}

2012 yılından beri uygulanan güncel teşvik sistemi, genel, bölgesel, büyük ölçekli ve stratejik olmak üzere dört farklı başlık altında uygulanmaktadır (Yatırım Ofisi t.y.). Turizm sektörü de bölgesel yatırım teşviklerinden yararlanmaktadır. Teşviklerin kapsamı başvurunun yapıldığ 1 bölgeye göre farklılık göstermekte olup, iller çok gelişmişten az gelişmişe doğru altı farklı bölgede toplanmıştır. Her il, kendi bölgesine verilen teşviklerden yararlanabilmektedir. İstisnai olarak, yatırımın kültür ve turizm koruma ve gelişim bölgelerinde (KTKGB) yapılması durumunda, yatırım yapılan bölgeye bakılmaksızın, teşvik başvurusu yapan kurumlar beşinci bölgenin haklarından yararlanmaktadırlar. Dolayısıyla beşinci bölgeden daha gelişmiş olan birinci ve dördüncü arasındaki bölgeler, KTKGB'de bulunmaları durumunda daha kapsayıcı teşviklerden yararlanabilmektedir. Turizm Teşvik Kanunu'nun teşvikle ilgili esaslar ve hükümlerini anlatan üçüncü bölümünde de belirtildiği gibi yatırım teşvikleri öncelikle KTKGB'ye, turizm merkezlerine ve Bakanlık tarafından belirlenen diğer öncelikli bölgelere verilmektedir. İlgili kanunda verilen teşviklerin bazıları; turizm kredileri, belirli koşulları sağlayan işletmelere vergi ödeme kolaylıkları, elektrik vd. ödemelerin tarifelerinin düşük olması, haberleşme aracı taleplerinde işlem önceliği, alkollü içki satış kolaylığı, belirli oranda yabancı personel çalıştırma izni, tatillerde çalışma izni, tanıtım amaçlı faaliyetlerde bir yılı geçen sürede sözleşme yapma hakkı şeklinde tanımlanmıştır. TC. Cumhurbaşkanlığı Yatırım Ofisi'nin resmî web sitesinde (v1.invest.gov.tr) yayınlanan bilgiye göre ise yeni sistemde bölgesel yatırım teşvikleri; KDV istisnası, gümrük vergisi muafiyeti, vergi indirimi, sosyal sigortalar prim desteği (işveren payı), faiz oranı desteği ve arazi tahsisini kapsamaktadır.

Turizmi Teşvik Kanunu'nda (1982) belirtildiği gibi Bakanlık, teşvik verdiği ancak süreçte eksikleri ortaya çıan işletmelere; uyarma, para cezası ve işletme belgesi iptali gibi cezai yaptırımlar uygulayabilmektedir. Cezai hükümlerin uygulanması, 2705 sayılı Turizm Teşvik Kanununun Cezai Hükümlerinin Uygulanması Hakkında Yönetmelik (2008) ile düzenlenmiştir. Teşvikin iptali hem denetimlerde raporlanan önemli kusurların bulunması, verilen uyarılara uygun olarak iyileştirmelerin yapılmaması gibi durumlar$\mathrm{da}$, hem de işletme iznine esas belgenin bakanlığa iletilmemesi, geçerliliğini yitirmesi gibi durumlarda gerçekleşebilmektedir (Turizmi Teşvik Kanunu M.34). Bakanlık, teşvik verilen ve teşvikleri iptal edilen kurumları Resmî Gazete'de ${ }^{3}$ aylık olarak yayınlamaktadır.

\section{KTKGB'lerin Durumu ve Teşvik Sürecindeki Yeri}

KTKGB'ler, Kültür ve Turizm Bakanlığı Yatırım ve İşletmeler Genel Müdürlüğü'ne bağlı bir komisyon tarafından belirlenmektedir (Bkz. Kül-

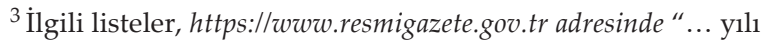
... ayına ait yatırım teşvik belgeleri listesi" başlığı altında ve tebliğ olarak yayınlanmaktadır.
} 
tür ve Turizm Koruma ve Gelişim Bölgeleri ile Turizm Merkezlerinin Belirlenmesine ve İlanına İlişkin Yönetmelik 1982). Kültür ve Turizm Bakanlığg' nın resmî web sitesinde yayınlanan listeye göre, Türkiye'de hâlihazırda 200 Turizm Merkezi (TM), 60 Kültür ve Turizmi Koruma ve Geliştirme Bölgesi (KTKGB), iki Turizm Bölgesi (TB) ve beş Turizm Alanı (TA) bulunmaktadır.

Bölgesel teşviklerde gelişmişlik açısından en iyi iller arasında (birinci bölge) olan Antalya, KTKGB'deki yatırımlar için beşinci bölgelere tanınan ayrıcalıklardan yararlanabilmektedir. Dolayısıyla Antalya ilinde faaliyet gösteren veya gösterecek bir işletmenin komple yeni yatırım teşvikine başvurması durumunda, işletmenin KTKGB'de olup olmaması, önemli bir etkendir. Tablo 1'de başvuru yapılan bölgeye bağlı farkl1lıklar, Yatırım Ofisi (t.y.) resmî web sitesindeki bilgilerden uyarlanarak karşılaştırmalı olarak belirtilmiştir.

\section{YÖNTEM}

Bu çalışmada Antalya ilindeki teşviklerin etkilerini anlamak ve ilerleyen yıllarda teşviklerin hangi alanlara kayması gerektiği ile ilgili öngörü kazanabilmek için; öncelikle son yıllarda verilen teşviklerin kapsamı birincil veri kullanılarak ortaya konulmuştur. Bunun için resmî gazetede yayınlanan aylık veriler derlenmiş ve bu veri seti incelenmiştir. Daha sonra bu teşviklerden yararlanan turizm işletmecilerinin konuya bakış açısı$\mathrm{n} ı$ anlamak için ikincil veri kullanılmıştır. Bu aşamada da elde edilen bulguları yorumlamak için uzman görüşleri alınmıştır.

Bilindiği gibi birincil verinin geçerliliği ve güvenilirliği doğası gereği yüksektir, çünkü yatırım teşviklerine dair yayınlanan liste doğrudan bulgulara işaret etmektedir. Diğer taraftan veri setinin aylık olarak yayınlanması ve sonrasında bu çalışma kapsamında bir Excel dosyasında toplanması sırasında oluşabilecek hata payını azaltmak için, toplanan veri setinin tamamı, ikinci bir parti tarafından kontrol edilmiştir. İkincil veri ise görüşmelere dayanmaktadır, görüşmeler güvenilirlik açısından aynı iki araştırmacı tarafından gerçekleştirilmiş ve yüz yüze yapılmıştır. Geçerliliğin yüksek olması için de görüşmeler iki araş-

Tablo 1. Antalya ili için bölgesel yatırım teşviki kapsamı

\begin{tabular}{|c|c|c|c|c|c|c|c|}
\hline \multirow{2}{*}{\multicolumn{2}{|c|}{ Destek kalemi }} & \multicolumn{2}{|c|}{$\begin{array}{c}\text { KTKGB içi } \\
\text { (Beşinci bölge) }\end{array}$} & \multicolumn{2}{|c|}{$\begin{array}{c}\text { KTKGB dışı } \\
\text { (Birinci bölge) }\end{array}$} & \multicolumn{2}{|c|}{ Fark } \\
\hline & & OSB içi & OSB dışı & OSB içi & OSB dışı & OSB içi & OSB dışı \\
\hline \multicolumn{2}{|c|}{ Vergi indirim oranı (\%) } & \multicolumn{2}{|c|}{80} & \multicolumn{2}{|c|}{50} & \multicolumn{2}{|c|}{30} \\
\hline \multicolumn{2}{|c|}{ Yatırıma katkı oranı (\%) } & 50 & 40 & 20 & 15 & 30 & 25 \\
\hline \multirow{2}{*}{$\begin{array}{c}\text { Sosyal Sigortalar } \\
\text { Prim Desteği } \\
\text { (İşveren Payı) }\end{array}$} & Süre (yıl) & 10 & 7 & 3 & 2 & 7 & 5 \\
\hline & Üst Sınır (\%) & 15 & 10 & Sınırsız & 35 & - & 25 \\
\hline \multirow{2}{*}{ Faiz oranı desteği } & $\begin{array}{l}\text { TL'ye endeksli } \\
\text { krediler (puan) }\end{array}$ & \multirow{2}{*}{\multicolumn{2}{|c|}{ Yok }} & \multicolumn{2}{|c|}{5} & \multicolumn{2}{|c|}{-} \\
\hline & $\begin{array}{l}\text { Dövize endeksli } \\
\text { krediler (puan) }\end{array}$ & & & \multicolumn{2}{|c|}{2} & \multicolumn{2}{|c|}{-} \\
\hline
\end{tabular}


tırmacı tarafından da bağımsız olarak değerlendirilmiştir.

Teşvik listeleri incelendiğinde öncelikle Antalya ili için verilen turizm teşviklerinin son beş senedeki durumu üzerine çalışılmıştır. Bakanlık tarafından verilen teşvikler ve teşvik iptal kararları, resmî gazetede aylık olarak yayınlanan listelerden çekilmiştir. 2634 sayılı Turizmi Teşvik Kanunu'na (1982) göre Bakanlık, denetleme neticesinde işletmelere uyarma, para cezası ve işletme belgesi iptali gibi cezalar verebildiği için, iptal edilen teşvikler de bu çalışmada dikkate alınmıştır. Bu veri seti betimleyici analiz çerçevesinde değerlendirilmiş, teşviklerin illere, yıllara, teşvik kapsamına göre dağılımlarına bakılmıştır.

Görüşmeler ise daha önce teşvikten yararlanmış bir konaklama işletmesi ve teşviklerden yararlanmamış konaklama işletmesi üst yöneticileri ile gerçekleştirilmiştir. Ayrıca sektördeki firmaların teşvik sürecinde danışmanlık hizmeti veren bir firmanın kurucusu ile görüşülmüştür. Firmaların seçilmesinde kartopu örneklem seçimi gerçekleştirilmiş, tavsiye doğrultusunda firmalara ulaşılmıştır.

Teşvik alan veya teşviklerle ilgili bilgisi olmayan konaklama işletmelerinin, süreci bir danışman aracilığıyla takip etmeleri sebebiyle, veri setiyle ilgili teknik sorular da danışmanlık firmasına yöneltilmiştir. Danışmanlık firmasına sorulan sorular aşağıdaki şekilde belirlenmiştir. Bu sorular, araştırmacıların elde edilen bulguları yorumlarken gerekli bilgiye dayanarak belirlenmiştir.

1. Yatırım teşviklerinde yerli ve yabancı sermayeli işletmeler için farklılık var mıdır?

2. Teşvik başvuru sayısı bazında başvuru kabul oranları nedir?

3. Antalya iline verilen teşvik miktarındaki göreceli azalmanın sebebi nedir?

4. Teşvik başvurusu ve kullanılması sürecinde karşılaştığınız olumlu ve olumsuz durumlar nelerdir?

5. Genel olarak turizm sektörüne ve Antalya'ya verilen teşviklerin gelecekte hangi kapsamda olması gerektiğini düşünüyorsunuz?
Teşvikten yararlanmayan firmalara, böyle bir teşvikten haberleri olup olmadığı ve eğer haberleri varsa neden teşvikten yararlanmak istemedikleri sorulmuştur. Teşvikten yararlanan konaklama işletmesi yöneticisine ise aşağıdaki sorular yöneltilmiştir. Bu sorular başvuru motivasyonunun anlaşılması ve teşviklerin gelecekte nasıl şekillenebileceğinin anlaşılmasına yöneliktir.

1. Başvurduğunuz desteğin/desteklerin kapsamı nedir?

2. Başvuru sürecinde yaşanan zorluklar nelerdir? Bu konuda dışarıdan danışmanlık desteği aldınız mı? Aldıysanız bunu gerekli görüyor musunuz?

3. Teşviklerden nasıl haberdar oldunuz? Üçüncü partilerin (sivil toplum örgütleri, danışman firmalar gibi) teşvik konusunda yatırımcılara yol göstermede yararlı olduğunu düşünüyor musunuz?

4. Sizce turizm sektörüne verilen teşvikler nitelik ve nicelik açısından yeterli midir? Teşviklerin kapsamı geliştirilebilir mi?

\section{BULGULAR VE YORUM}

Bu başlık altında önce birincil veriden elde edilen bulgular tartışılarak yorumlanmış, daha sonra ikincil veri olan görüşmelerin bulguları paylaşılmiştır.

\section{Turizm Teşvik ve Teşvik İptali Listeleri}

Antalya'daki bölgelere bakıldığında, en fazla destek Alanya ve sonrasinda Manavgat bölgesinde görülmektedir. Alanya'ya verilen desteklere bakıldığında, 2012 yılında beş farklı bölge golf turizmi temasıyla turizm merkezi ilan edilmiştir. Golf dışında çeşitli bölgelere kıyı, kış, kongre ve yayla turizmi için destek verilmiştir. 2015 yılında, sadece Serik bölgesine özel olarak, bu bölge eko-turizm ve golf için koruma ve geliştirme bölgesi olarak belirlenmiştir.

Teşvik listelerinde verilen yatırım kapasitesine yönelik bilgiye göre, turizm alanında verilen teşvikler genellikle üç-dört-beş yıldızlı otel, öğrenci yurdu, butik otel, kongre ve sergi merkezi ile balon, hava gemisi, motorsuz hava taşıtları alanla- 
rında yatırımlara dönüşmüştür. Sadece Antalya iline verilen teşviklere bakıldığında, 2014-2018 yılları arasinda toplam $229 \mathrm{kalem}^{4}$ ile toplamda yaklaşık 6.438.000.000 TL (brüt) sabit yatırım desteğ $i^{5}$ verilmiştir; yine aynı yıllar içinde toplamda yaklaşık 1.685.000.000 TL değerindeki sabit yatırım desteği iptal edilmiştir. Bu değerler Türkiye genelindeki değerlerle karşılaştırıldığında (Şekil 1), turizm alanında verilen brüt teşvik miktarlarının hem ulusal anlamda hem de il genelinde 2014-2016 yılları arasında azaldı $\breve{g}_{1}, 2017$ yılındaki artışın ardından 2018 yılında tekrar azaldığı görülmektedir. İptal edilen teşvikleri de dahil ederek net teşvik değerlerine bakıldığında ise Antalya ilinin aldığ 1 teşvikin Türkiye genelindeki ortalamasının da 2014-2016 yılları arasında önemli oranda düştüğü görülmektedir. Bu düşüşte, 2017 ve 2018 yıllarında Antalya'dan alınan brüt teşvikin sırasiyla yüzde 36 ve yüzde 33'ünün iptal edilmesi de (bu oran Türkiye geneli için sırasıyla yüzde 29 ve yüzde 16'dır) etkilidir.

2014-2018 yılları arasında en fazla net teşvik alan ilk beş şehre verilen teşvik miktarının zamana bağlı olarak değişimine bakıldığında (Şekil 2), İstanbul ve İzmir illerinde yıllar içinde önemli bir değişim olmazken, Antalya ilinde 2014-2016 yılları arasında önemli oranda düşüş görülmekte, Trabzon ilinde ise 2018 yılında önemli bir artış görülmektedir. Nihayetinde 2018 verilerine göre en fazla net teşvik Antalya, İstanbul ve Trabzon illerine verilmiştir. Karadeniz bölgesindeki en büyük oda potansiyeline sahip iki şehirden biri

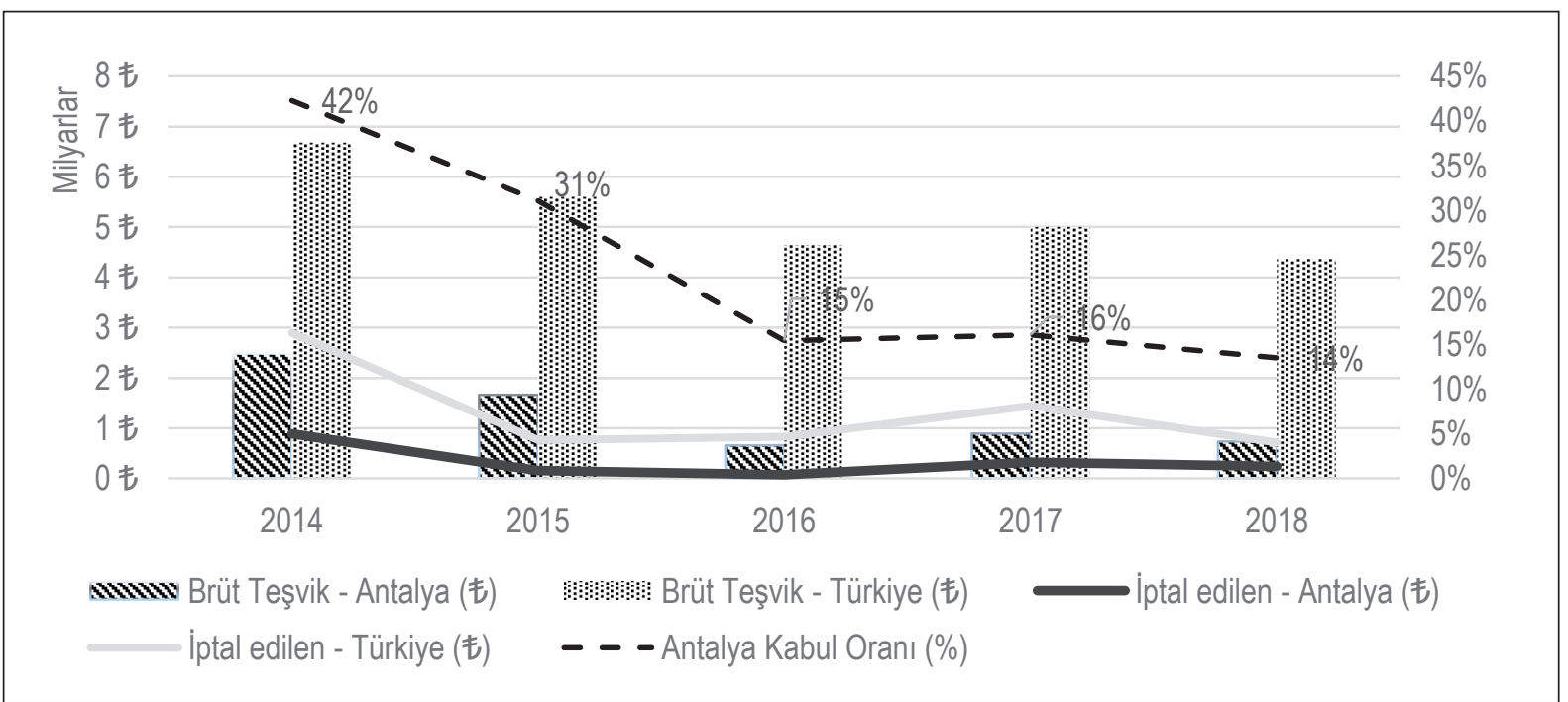

Şekil 1. 2014-2018 Yılları Arasında, Türkiye Geneli ve Antalya İli için Verilen ve İptal Edilen Sabit Yatırım Teşviklerinin Değerleri ve Antalya'nın Verilen Net Teşvik Miktarı İçindeki Yüzdesel Payı

\footnotetext{
${ }^{4}$ Bu bölümde bahsedilen "229 kalem", 229 firma olarak algilanmamalıdır. Kimi firmalar birden fazla teşvik aldığı için teşvik başvurusu yapan firma sayısı 229 'dan azdır. Bu bilgi sadece 229 satırdan oluşan veri setini ifade etmektedir. Ayrıca kimi firmaların reddedilen bir teşvik başvurusunun ardından tekrar başvuru yapmış olabileceği ihtimali de göz önünde bulundurulmalıdır. Bu sebeple teşvik miktarları hesaplanırken, teşvik listesinde ilan edilen değer "brüt değer", iptal edilen değerin düşülmesinden sonra elde edilen teşvik değeri ise "net değer" olarak adlandırılmıştır.

${ }^{5}$ Yatırım teşvik listelerinde sabit yatırım değerinin yanı sıra ithal makine teçhizat teşviki de verilmektedir, ancak bu teşvik miktarı sabit yatırım desteğinin yanında oldukça düşük bir değerde olması sebebiyle bu çalışma kapsamında yapılan analizlerde kullanılmamıştır.
}

olan Trabzon'a verilen desteklerin artışı, alternatif bir turistik çekicilik yaratma çabası ile açıklanabilir.

İptal edilen teşvikler sebebiyle net değer kimi aylarda sıfırın altında çıkmaktadır. Bu durum iptal oranlarını akla getirmektedir. Görüldüğü gibi Antalya için en yüksek iptal oranı yüzde 36 'dır (Şekil 3). Türkiye geneli ile karşılaştırıldığında son iki yılda Antalya'dan yapılan başvuruların iptal edilme oranı, diğer illerin ortalamasından daha yüksektir. 


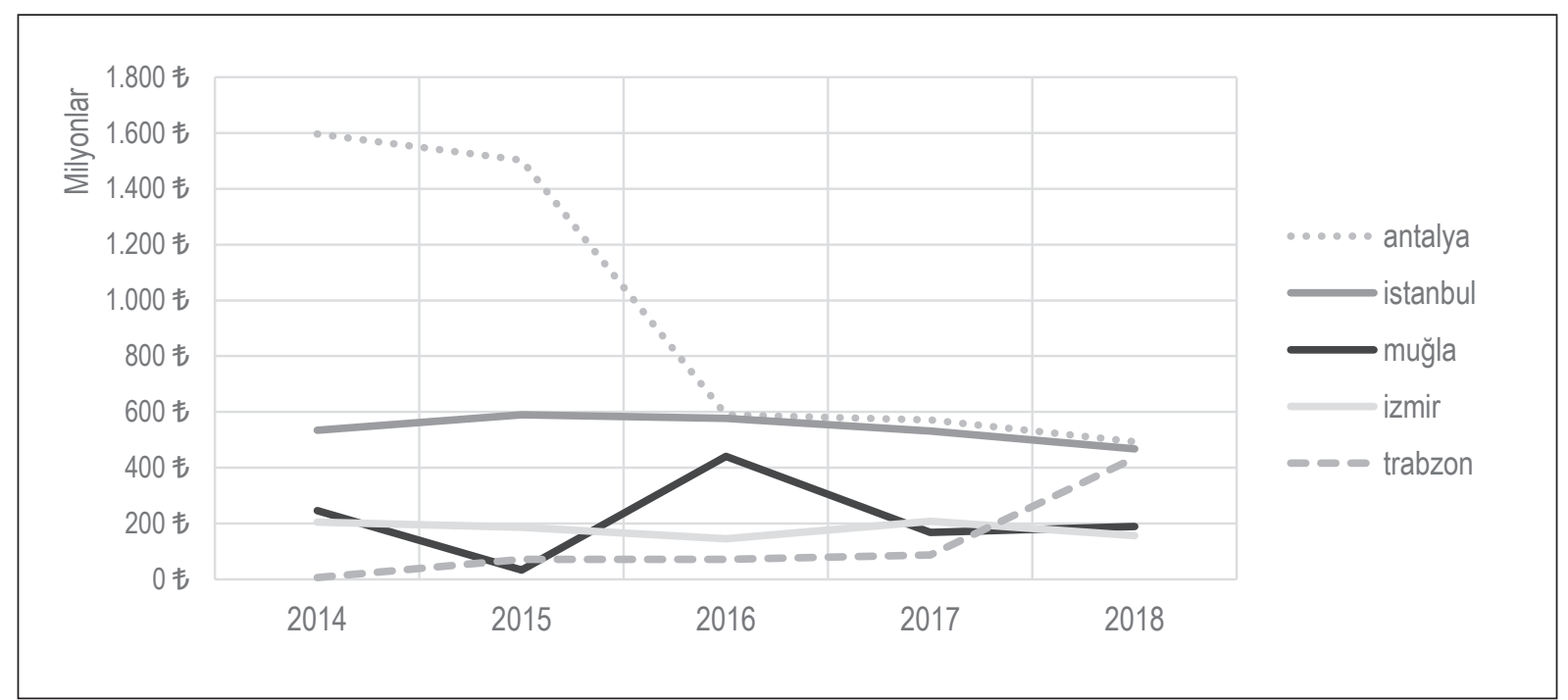

Şekil 2. 2014-2018 Yılları Arasında Toplamda En Fazla Net Sabit Yatırım Teşviki Alan Beş İl için Alınan Net Sabit Yatırım Teşvik Değerlerinin Yıllara Göre Değişimi

Yatırım teşvikleri aynı zamanda istihdam da sağlamaktadır ve 2014-2018 arasında teşvikler sayesinde sağlanan istihdam rakamlarına bakıldığında, 2014 yılında turizm alanında Türkiye genelinde sağlanan istihdamın yüzde $64^{\prime} \ddot{u}^{6} \mathrm{An}$ talya ilinde iken, bu oran 2018 'de en düşük seviyesine gelmiştir (Şekil 4). 2014-2018 yılları arasında Antalya ilinde sağlanan istihdamın ortalaması 2286'dır ve bu değer üzerinde 2015 yılında 5132 kişiye istihdam sağlanması önemli bir etki yaratmıştır.

Elde edilen bu bulguların yorumlanması, resmî gazetede yayınlanan teşvik verilen ve teşvik desteği iptal edilen işletmeler listesindeki kısıtlı bilgi sebebiyle zorluklar taşımaktadır. Bu listelerde iptal edilen teşviklerin neden iptal edildiğine dair açıklama bulunmaması, hangi takip numaralı teşvikin iptal edildiğinin bilinememesine sebep olmuştur.

\section{Görüşme Sonuçları}

Bakanlık tarafından verilen teşvikler, teşviki alan işletme, teşvik verilen il, sabit yatırım teşviki, de-

\footnotetext{
${ }^{6} \mathrm{Bu}$ değer net istihdam değerleri üzerinden hesaplanmıștır. Net istihdam değeri, net teşvik değeri gibi kabul edilen (brüt) istihdam sayılarından, iptal edilen istihdam sayılarının düşülmesi sonucu elde edilen değerdir.
}

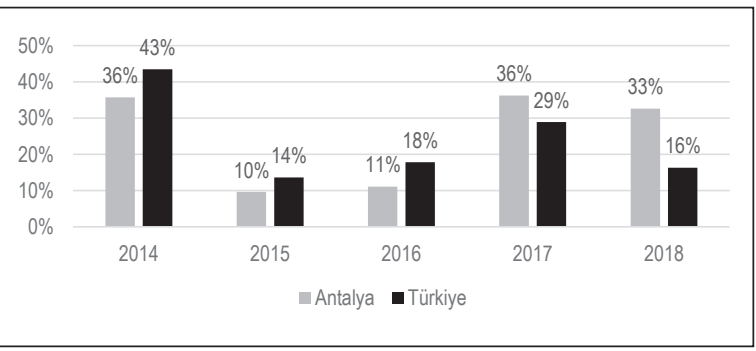

Şekil 3. 2014-2018 Yıllarında Türkiye Genelindeki ve Antalya İline Verilen Brüt Yatırım Teşvik Değerlerinde İptal Oranları

tayları ile birlikte, resmî gazetede aylık olarak yayınlanmaktadır. 2014-2018 yılları arasında yayınlanan yatırım teşvik listesi ve teşvikleri iptal edilenler listesi incelenerek, son beş yıla ait yatırım teşvik veri seti oluşturulmuştur. Bu listeler iki farklı liste şeklindedir ve listelerde hangi teşvikin iptal edildiği takip edilememektedir. Dolayısıyla beş yıllık veriye dayanarak değerlendirme yapılmıştır. Bu veri setinden yola çıkarak yapılan betimleyici istatistik analizleriyle, Antalya'ya verilen teşvikler il bazında (Tablo 1), iller arasında (Şekil 2) ve Türkiye ortalamasına kıyasla (Şekil 2, 3 ve 4) değerlendirilmiştir.

Veri setinin yorumlanmasinda, bu alanda hizmet veren bir danışmanlık firmasının desteği alınmıştır. Yapılan görüşme sonucunda yatırım teşviki başvurularının yıl boyunca yapılabildiği 


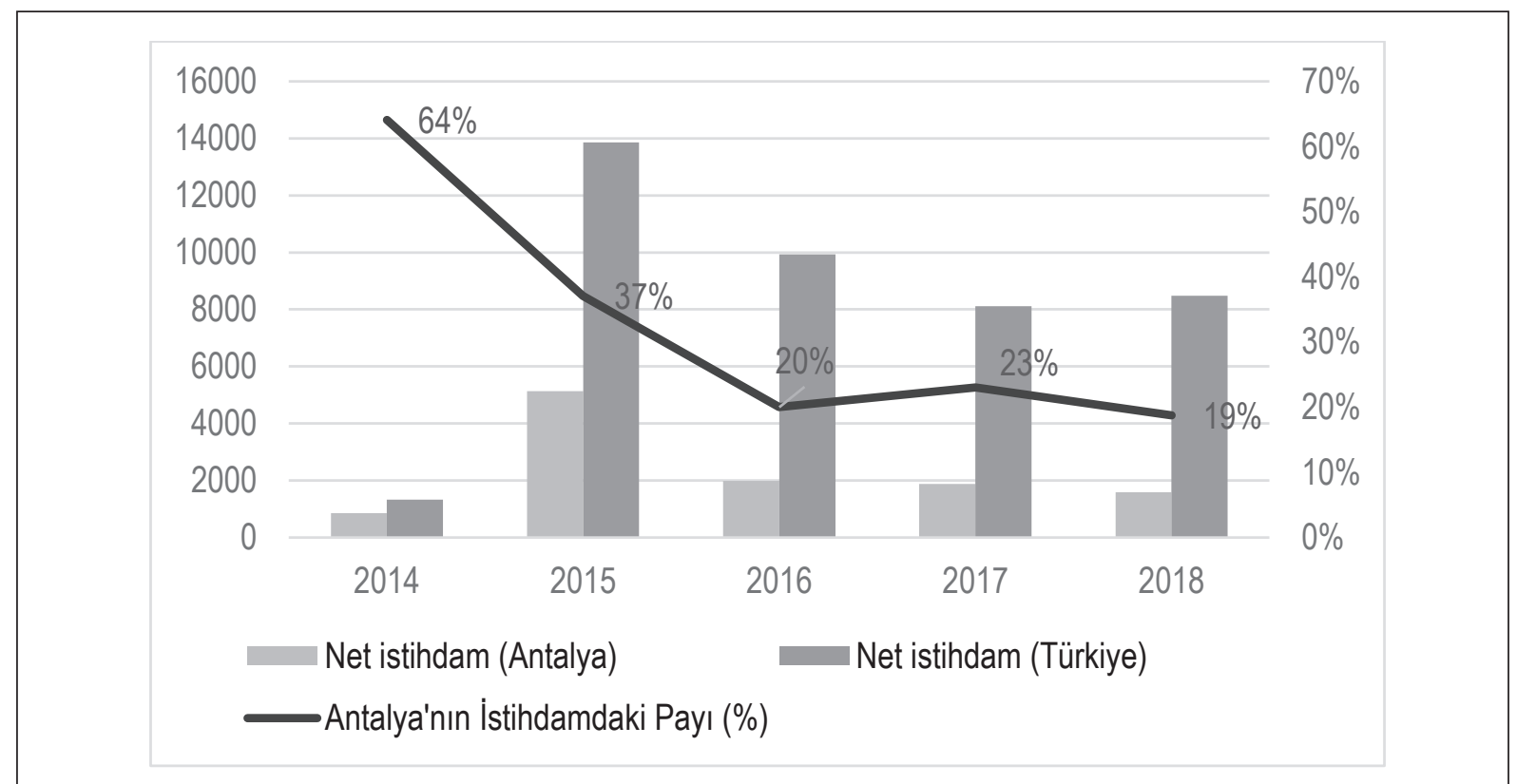

Şekil 4: Yatırım teşvikleri ile sağlanan net istihdam sayısının Antalya ve Türkiye genelinde değerlerinin 2014-2018 yılları arasındaki değişimi ve Antalya'nın sağlanan toplam net istihdam içindeki oranı (yüzde)

anlaşılmıştır. Yabancı ve yerli firmalar aynı teşvike başvurabilmekte ve uygun koşulları taşıyan her turizm firması bu desteklerden yararlanabilmektedir. Bunun yanı sıra teşviklerin; komple yeni yatırım, tevsi ve modernizasyon olarak s1nıflandırıldığı bilinmektedir. Tevsi ve modernizasyon arasındaki farkı yatırım teşvik danışmanı şu şekilde açılamaktadır;

“Komple yeni yatırımda bir arsanız var ve otel inşa edeceksiniz. Bununla ilgili Kültür ve Turizm Bakanlığı'ndan yatırım belgesi alıyorsunuz ve bu belgeyle birlikte Sanayi ve Teknoloji Bakanlığ Teşvik Uygulama Genel Müdürlüğ̈̈'ne müracaat ediyorsunuz. Orada size yatırım teşvik belgesi düzenleniyor. Kültür ve Turizm Bakanlığı'ndan alınan yatırım belgesiydi, bu ise teşvik belgesidir. Yatırım belgesi olmadan teşvik belgesi zaten düzenlenmiyor. İşte bu komple yeni yatırıma giriyor. Tevsi kavramina gelince, bu kelimenin diğer anlamı genişleme, büyümedir. Oda sayınız 100'dür, siz bu sayıyı 120'ye çıkartmak istiyorsunuz, o zaman tevsi desteği alırsınız. Modernizasyonda ise üç tane odanız vardır, oda sayınızı arttırmadan sadece otelinizi modernize etmek istiyorsunuz, dolayısıyla halı, perde gibi eşyaların yenilenmesini kapsar."
Görüşme yapılan beş yıldızlı bir zincir otel grubunun ${ }^{7}$ Yönetim Kurulu Başkanı ile yapılan görüşme sonucu elde edilen verilere göre, ilgili işletme modernizasyon ve komple yeni yatırım destekleri olmak üzere toplam dört defa teşvik almıştır. En son alınan komple yeni yatırım desteği 2011 yılında onaylanmıştır, ancak 2019 yılında binanın inşasına başlanabilmiştir. Süreçte bir danışmanlık firmasından destek alınmıştır. Danışmanlık firması, işletmenin muhasebe birimi ile ortak çalışmaktadır. Yeminli mali müşavirlerin de teşvik süreçlerinden haberdar olduğunu ve internette bu konuda bilgiye ulaşılabildiğini ifade eden Yönetim Kurulu Başkanı açısından, teşvik konusunda haberdarlık farklı kanallardan gerçekleşebilmektedir. Buna karşın sivil toplum örgütlerinin yatırım teşviklerine yönelik etkinliklerini değerlendirdiğinde, STK'ların bu konuda aktif olmadı ̆̆ 1 ifade edilmiştir. Yapılan görüşme sonucunda, yatırım teşvik süreçlerinde

\footnotetext{
${ }^{7}$ Görüşme yapılan kişinin kimliği gizlenmiştir. İlgili konaklama işletmesi Antalya ilinde Kültür ve Turizm Koruma ve Gelişim Bölgesinde faaliyet gösteren, ağırlıkla Batı Avrupalı turistleri ağırlayan bir firmadır.
} 
dört ana unsurla ilgili iyileştirme yapılabileceği anlaşılmıştır. Birinci alan modernizasyon desteğinin uygulama esaslarına yönelik mevzuattaki belirsizliğin giderilmesi ve modernizasyon kapsamının genişletilmesine yöneliktir. İkinci alan kış sezonunu geliştirici teşviklerin arttırılması, özellikle yeni açılan oteller için, ilk birkaç yıl, kış sezonunda da işveren primlerine yönelik indirimlerin verilmesi yönündeki önerilerdir. Böylece işgücünde mevsimsellik sorununa yönelik bir iyileştirme söz konusu olacaktır. Üçüncü alan başvuru süreci ve başvurunun kabul edilmesini takip eden süreçlerdeki bürokrasinin azaltılması yönündedir. Benzer şekilde danışmanlık firması yetkilisi de başvuru ve kabul edilen başvuruların takip süreçlerinde danışmanlık firmalarına düşen bürokratik işlerin azaltılması yönünde iyileştirme yapılabileceğini ifade etmiştir. Son olarak da turizmi çeşitlendirecek, sezonu uzatacak ve kış aylarını da cazip hale getirecek konularda yatırımcı teşviklerinin özendirilmesi ve geliştirilmesi konusuna değinilmiştir.

\section{SONUÇ VE ÖNERILER}

Araştırmadan elde edilen bulgulara göre, öncelikle turizm sektöründe teşvik kullanımının önemini koruduğu anlaşılmaktadır. Yatırım danışmanının ifade ettiği gibi "Her otel teşviklerden yararlanıyordur, sonuçta kurumlar vergisi indirimi önemli.". Buna karşın Antalya iline verilen teşvik miktarında zamanla düşüş gözlenmektedir. İlk bakışta işletmelerin teşvik konusunun farkında olmayabileceği düşünülmektedir, ancak bu düşüşü yatırım teşvik danışmanı şu şekilde yorumlamıştır; "Talep azaldığı için, alan kalmadı̆̆ı için teşvik başourusu azaldı. Yer olsa otel sahipleri başvuru yapar". Danışman, ek olarak otel sahiplerinin oda sayısına önem verdiğini ve kimi zaman bu sebeple ek hizmetler için alan kullanmaktan kaçındığını da vurgulamıştır. Bu ifadeler mevcut KTKGB'lerdeki alan sorunlarına işaret etmektedir.

İkinci olarak, KTKGB'de kurulan otellerin, büyük yatırımlar olduğu, bu yatırımların neticesinde de kitle turizmine yönelik, yüksek yatak kapasiteli otellerin hizmet verdiği anlaşılmaktadır. Yatırım teşvik süreçleri ile desteklenen bu olu- şum, yüksek kapasiteli kitle turizminin gelişimine önemli şekilde vesile olmuştur. Günümüzde Antalya'da ağırlıkla tercih edilen her şey dahil hizmetinin, yine bu teşvik sistemi sebebiyle geliştiği düşünülmektedir.

Yatırımın hangi ilde ve hangi alanlara yapılması gerektiği de diğer bir tartışma konusudur. Bu konunun kapsamlı bir turizm planlaması ile çözümlenebileceği düşünülmektedir. Örneğin hem Antalya'da yatırım teşviki talebinin azalması, hem de pik sezonda konaklama işletmelerinin yüksek kapasitede çalışmasına rağmen sezon sonundaki işsizlik sorununa yönelik bir politika izlenmesi önerilebilir. Bu planlama kapsamında, yatırım teşviklerinin bir anlamda haksız rekabete sebep olabileceği de göz önünde bulundurulmalıdır. Bu çalışma kapsamında görüşülen Yönetim Kurulu Başkanı konuyu şu cümlelerle ifade etmiştir; "... (verilen teşvikler) [H]aksız rekabet oluşturacaksa niye (devlet) yatırımı teşvik etsin? Bunu da düşünmek lazım. Aşırı teşvik de diğer taraftan haksız rekabeti teşvik ediyor. Devletin burada ihtiyacı belirlemesi gerekiyor". Yavan (2012), yapmış olduğu çalışmada, Türkiye'deki turizm teşviklerinin yüksek gelirli illere daha fazla verildiği sonucuna ulaşmış ve teşvik dağıtımının gözden geçirilmesi gerektiğini vurgulamıştır. Bu çalışmada da benzer bir gereksinim ortaya çıkmıştır. Turizm merkezleri açısından en fazla desteğin Antalya ve İstanbul, ardından sırasıyla İzmir ve Muğla tarafından alınması bu duruma örnektir.

Yatırım teşviklerinin farklı sebeplerle verildiği bilinmektedir. Türkiye'deki sistemde bu teşvik türlerinden sabit yatırım teşvikinin, ağırlıkla üçdört-beş yıldızlı otellerin yapımı için kullanıldığ1 görülmektedir. Ancak Antalya için konaklama tesisi yatırımlarından çok alternatif turizme dikkat çekilmesi gerektiğini vurgulayan sektör ve sivil toplum örgütü temsilcileri bulunmaktadır (Arabacı 2012; Budak 2012). Örneğin Alanya ilçesi için golf turizmine sağlanan turizm merkezi ayrıcalıkları bu bölgenin gelişimi için önem taşımaktadır. 2016 yılında il bazında ortalama doluluk oranı yüzde 47 iken, golf tesislerinin yüzde 96 ile en fazla doluluk oranı veren tesis türü olması (Yatırım ve İşletmeler Genel Müdürlüğü 2016), bahsi geçen yatırım teşviklerinin etkisini göstermektedir. 
Yeni açılan otellerle rekabet etmek ve değişen turist profiline uyum sağlamak zorunda olan 1980 sonrasinda kurulan otellerin, hem teknolojik anlamda hem de konsept anlamında yenilenmesi gerekli görülmektedir (Gündoğdu 2012; Kabadayı 2012; Uçar 2012). Bu durumda, teşviklerin modernizasyon ağırlıklı ve kış sezonunda talep gören turistik faaliyetlere göre verilmesi, mevsimsel işsizlik sorununa ve azalan teşvik talebine çözüm oluşturabilecektir. Antalya ili teşvik başvurularının KTKGB kapsamında yapılmasında önemli avantajlar olduğu anlaşılmaktadır ve bu avantajlar firmalar tarafından etkin bir şekilde kullanılmıştır. Antalya'daki işletmelerin gelişebilmesi için ise bu bölgelerin dişında kalan alanlar için de benzer teşviklerin bölgesel gelişim aç1sından önemli olduğu düşünülmektedir. Aynı sebeplerle, konaklama işletmelerinin revize edilmesi önerilen yatırım teşvik imkanları ile ilgili bilgilendirilmesi gerekmektedir. Mali müşavirlerin bilgi aktarma sürecindeki rolü bilinmektedir. Buna ek olarak sivil toplum örgütlerinin de, farklı iletişim kanalları kullanarak teşvik süreçleri ile ilgili işletmeleri yönlendirerek sürece daha yüksek katkı sağlamasının yararlı olacağı düşünülmektedir.

Mevcut teşvik kapsamı düşünüldüğünde hem danışmanlık firması hem de teşvik alan otel görüşmesinde, otelcilik sektörünün KDV indiriminden yararlanması yönünde benzer bir yorum yapılmıştır. Bahsi geçen yüksek kapasiteli işletmelerin yüksek gelirleri olduğu için, KDV indiriminin önemli bir destek olmadığ ${ }_{1}$ ifade edilmektedir. Buradan yola çıkarak KDV indiriminin düşük kapasiteli oteller için daha önemli olduğu ve böyle bir imkânın kitle turizmi dişında daha müşteri odaklı turizm yapan işletmelerin desteklenmesi açısından gerekli olduğu düşünülmektedir. Sadece Antalya ili için değil, dünya genelinde de turistin özgür davranmayı seven, kişiselleştirilmiş hizmetler arayan bireylere dönüştüğü düşünülerek, bu yeni profile de uygun bir destek planına gereksinim duyulmaktadır.

Bu çalışmada değinilmeyen ancak konuya farklı bir yaklaşım sunacak sürdürülebilirlik konusu, araştırmacılar ve uygulayıcılar için farklı bir araştırma alanı olabilir. 2014-2018 yıllarında en fazla sabit yatırım teşviki alan Antalya'nın, bu süreçte ekolojik ve çevresel altyapısı, sürdürülebilirliğin önemli bir boyutu olarak düşünülmelidir. Örneğin, golf turizmi açısından Alanya bölgesinin yatırımlara açık olduğu anlaşılmaktadır. Diğer taraftan golf sahası açarken, orman alanlarının kullanılması sebebiyle çevreye verilebilecek zararın (Yücel 2012) önüne geçecek önlemler alınmalıdır. Ekolojik açıdan değerli alanlarda turistik tesis açılması gündemde olan bir konudur. TEMA Vakfı'nın (2005) Antalya Manavgat ilçesine bağlı Sorgun Ormanı'na golf tesisi yapılmaması için başlattığı yasal süreç bu olaylara örnek olarak gösterilebilir (Sönmez 2005; Radikal 2007). Benzer bir olay 2017 yılında yine Manavgat ilçesinde yaşanmıştır (Hürriyet 2018; DHA 2019). Bu olaylardan yola çıkarak yatırım kararlarında, bölgenin yerel halkını ve doğasının da süreçten etkilendiği göz önünde bulundurulmalıdır.

Kitle turizminin yatırım teşvikleri ile doğrudan ilişkisi bu çalışma kapsamında incelenmemiş olmakla birlikte, kitle turizmi sosyo-ekonomik açıdan hâlihazırda tartışılan bir konudur. Bu tartışmaların bir bölümü konaklama işletmesini tatili boyunca terk etmeden, ziyaret ettiği bölgenin kültüründen uzak tatil yapan turist harcamalarının, sadece konaklama işletmesinde kalmasına yöneliktir. Karşıt görüş olarak, şehrin altyapı yetersizliği sebebiyle ancak her şey dahil hizmetin tercih edilebileceği ifade edilmektedir. Dolayısıyla ileride yapılacak çalışmalarda turizm teşviklerinin dağılımı ve bu dağılımın kitle turizmine etkisi üzerine bir tartışma yürütmek yararlı olacaktır.

Türkiye'deki turizm teşvik sisteminin başka ülkelerle karşılaştırılması da araștırmacılar için ilgi çekici bir çalışma alanı olabilir. Bu incelemelerde devletlerin ekonomik politikalarındaki farklılıkların, belirli sektörlere ayrıcalıklar tanıyarak pazara müdahale etme konusundaki karar mekanizmasını etkilediği de göz önünde bulundurulmalıdır (Wanhill 2005). Bu sürece kültürel değerlerin korunması ve tanıtımı konusu da dahil edilebilir. Neticede Türkiye'deki kültür ve turizmi geliştirme bölgelerine sağlanan ayrıcalıklar incelendiğinde, mevcut sisteminde kültürel mirasa yönelik bir ayrım yapılmadığı anlaşılmak- 
tadır. Teşviklerin kültürel mirası korumaya ve tanıtmaya yönelik yapılandırılması için farklı ülkelerdeki uygulamaların yol gösterici olabileceği tahmin edilmektedir.

\section{KAYNAKÇA}

Andaç, F. (2013). Turizm Hukuku. 5. Bask1. Ankara: Detay Yayincilik.

Arabacı, H. (2012). Antalya Konaklama Yatırımlarına Doydu, Röportaj: Asteria Hotels / Hikmet Arabac1, Turizm ve Yatırım İsletme ve Endüstri Dergisi, 2: 26-27.

Bahar, O. (2010). Turizm Sektörüne Sağlanan Doğrudan Yabancı Sermaye Yatırımlarının (DYSY) Ekonomik Büyüme Üzerine Olan Olası Etkisi: Türkiye Örneği (19862006), Anatolia: Turizm Araştırmaları Dergisi, 21 (1): 27-40.

Bodlender, J. A. (1982). The Financing of Tourism Projects, Tourism Management, 3(4): 277-284.

Budak, O. (2012). Antalya Ticaret ve Sanayi Odası (ATSO) Başkanı ile Röportaj, Turizm ve Yatırım İşletme ve Endüstri Dergisi, 2: 23.

Dalgın, T., Karadăg, L. ve Bingöl, Z. (2015). Türkiye'de Turizm Girişimciliğinin Gelişimi ve Turizmle İlgili Sağlanan Teşvikler, Muğla Sıtkı Koçman Üniversitesi İktisadi ve İdari Bilimler Fakültesi Ekonomi ve Yönetim Araştırmaları Dergisi, 4 (1): 174-184.

Demirören Haber Ajansı [DHA] (2019). Manavgat'ta Ağaç Kesimi Protestosu, https://www.haberler.com/manavgatta-agac-kesimi-protestosu-11600008-haberil, Erişim tarihi: 2 Ağustos 2019.

Gündoğdu, N. (2012). Avrupalılara Göre Yapılan Tesisler Ruslara Göre Değiştiriliyor, Turizm ve Yatırım İşletme ve Endüstri Dergisi, 2 : 10.

Hürriyet (2018). Sorgun Ormanı'nda Turizm Tesisi İçin Ağaç Kesimi, http://www.hurriyet.com.tr/yerel-haberler/antalyal manavgat/sorgun-ormaninda-turizm-tesisi-icin-agac-kesim-41063354, Erişim tarihi: 2 Ağustos 2019.

Jenkins, C. L. (1982). The Use of Investment Incentives for Tourism Projects in Developing Countries, Tourism Management, 3 (2): 91-97.

Jenkins, C. L., ve Henry, B. M. (1982). Government Involvement in Tourism in Developing Countries, Annals of Tourism Research, 9 (4): 499-521.

Kabadayı, O. (2012). Devletin Renovasyon Yatırımlarına Destek Vermesi Lazım, Turizm ve Yatırım İşletme ve Endüstri Dergisi, 2: 12.

Kasalak, K. (2012). Teşvik-i Sanayi Kanunları ve Türkiye'de Sanayileşmeye Etkileri, SDÜ Fen Edebiyat Fakültesi Sosyal Bilimler Dergisi, 27: 65-79.

Kültür ve Turizm Koruma ve Gelişim Bölgeleri ile Turizm Merkezlerinin Belirlenmesine ve İlanına İlişkin Yönetmelik (1982). T.C. Resmî Gazete, No: 25463.

Oduro-Ofori, E. (2011). The Role of Local Government in Local Economic Development Promotion at the District Level in Ghana (Doktora Tezi). Dortmund: Technical University of Dortmund.

Özgen, F. B. (2013). The Effectiveness of Governmental Incentives in the Turkish Tourism Sector and the Relations- hip between Incentives and Tourism Revenue. 8th Silk Road International Conference on Development of Tourism in Black and Caspian Seas Region (ss. 11-16). Gürcistan: Tiflis-Batum.

Radikal (2007). Sorgun'a Golf Sahası Durduruldu, http:// www.radikal.com.tr/turkiye/sorguna-golf-sahasidurduruldu-802364/, Erişim tarihi: 2 Eylül 2019.

Sönmez, D. (2005). Sorgun AİHM'ye, DHA, http://www.hurriyet.com.tr/gundem/sorgun-aihm-ye-342869, Erişim tarihi: 2 Eylül 2019.

Şahin, M., ve Uysal, Ö. (2011). Bölgesel Kalkınma Çerçevesinde Yatırım Teşviklerinin Shift-Share Analizi, Maliye Dergisi, 160 (Ocak-Haziran): 111-138.

Şanlıŏlu Ö. ve Özcan E.Ö., (2017). Türkiye'de Uygulanan Turizm Teşvik Politikaları ve Sonuçları Üzerine Bir Değerlendirme, Kirıkkale Üniversitesi Sosyal Bilimler Dergisi, 7 (2): 97-118.

Türkiye Erozyonla Mücadele Ağaçlandırma ve Doğal Varlıkları Koruma Vakfı [TEMA] (2005). Sorgun Ormanı'nın Tahrip Edilerek Golf Sahası Yapılması, Ekolojik, Sosyal, Kültürel, Tarihsel, Bilimsel ve Hukuki Açılarından Yanlıştır. http://www.tema.org.tr/web_14966-2_1/ entitialfocus.aspx?primary_id $=731 \mathcal{E}$ type $=2 \mathcal{E}$ target $=$ categ

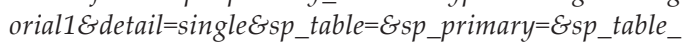
extra=Eopenfrom=sortial, Erişim tarihi: 5 Eylül 2019.

Toker, B. (2007). Türkiye'de Turizm Sektörü Teşviklerinin Değerlendirilmesi, Yönetim ve Ekonomi, 14 (2): 81-92.

Turizm Teşvik Kanununun Cezai Hükümlerinin Uygulanması Hakkında Yönetmelik (2008). T.C. Resmî Gazete, No: 27025.

Turizm ve Yatırım İşletme ve Endüstri Dergisi (2012). Türkiye Turizm Yatırımlarında Bir Başarı Hikayesi Yazdı, Turizm ve Yatırım İşletme ve Endüstri Dergisi, 1 (Ağustos): 6-9.

Turizmi Teşvik Kanunu (1982). T.C. Resmî Gazete, No: 2634.

Türkiye Cumhuriyeti Cumhurbaşkanlığ 1 Strateji ve Bütçe Başkanlığı (2019). On Birinci Kalkınma Planı 20192023, http://www.sbb.gov.tr//wp-content/uploads/2019/07/ On-Birinci-Kalkinma-Plani.pdf, Erişim tarihi: 9 Ağustos 2019.

Uçar, A. İ. (2012). Şehir Otelinde Renovasyon Daha Zor, Turizm ve Yatırım İşletme ve Endüstri Dergisi, 2 :12.

Wanhill, S. R. (1986). Which Investment Incentives for Tourism?, Tourism Management, 7 (1): 2-7.

Wanhill, S. R. (2005). Role of Government Incentives. İçinde W.F. Theobald (Editör), Global Tourism (ss. 367-390). Massachusetts: Butterworth-Heinemann.

Yatırım Ofisi. Teşvikler: Yatırım Teşvikleri, http://v1.invest.gov. tr/tr-TR/investmentguide/investorsguide/Pages/Incentives. aspx, Erişim tarihi: 7 Eylül 2019.

Yatırım ve İşletmeler Genel Müdürlüğü (2016) Konaklama İstatistikleri, https://yigm.ktb.gov.tr/TR-9857/isletme-belgeli-tesisler.html , Erişim tarihi: 7 Eylül 2019.

Yavan, N. (2012). Türkiye'de Yatırım Teşviklerinin Bölgesel Belirleyicileri: Mekânsal ve İstatistiksel bir Analiz, Coğrafi Bilimler Dergisi, 10 (1): 9-37.

Yücel, B. (2012) Türkiye Turizm Politikalarında Genel Olarak Başarılı Oldu. Röportaj, Turizm ve Yatırım İşletme ve Endüstri Dergisi, 1: 14-15. 

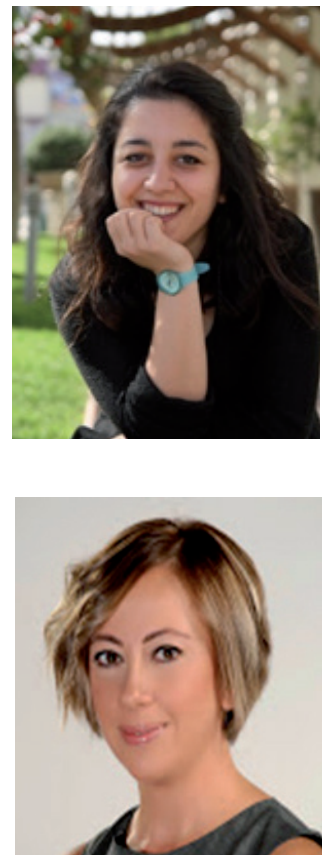

\section{Eda Evla MUTLU}

Ege Üniversitesi Mühendislik Fakültesi, Gıda Mühendisliği Bölümü’nden mezun oldu (2009). Birinci yüksek lisans derecesini İstanbul Üniversitesi'nden MBA Programı'ndan (2012), doktora derecesini de Yaşar Üniversitesi'nden İşletme Ana Bilim Dalı'ndan aldı (2017). İkinci yüksek lisans derecesini Ege Üniversitesi Sosyal Bilimlerde İnsan Çalışmaları Programı́ndan aldı (2018). Yaşar Üniversitesi Turizm ve Otel İ̧̧letmeciliğ Bölümü'nde araştırma görevlisi olarak çalışmaya başladı (2015). Daha sonra Antalya Bilim Üniversitesi Turizm Fakültesi'nde doktor öğretim üyesi olarak işe başladı (2018). Halen aynı fakültede görev yapmaktadır. Temel çalışma alanları yönetim, örgütsel davranış, girişimcilik, turizm, sosyal ağlar ve işbirlikleridir.

\section{Gözdegül BAŞER}

Ortadoğu Teknik Üniversitesi, İktisadi ve Idari Bilimler Fakültesi İsletme Bölümü'nden mezun oldu (1992). Yüksek lisans derecesini Akdeniz Üniversitesi'nden Turizm İşletmeciliği Dalı'ndan (1995), doktora derecesini de Akdeniz Üniversitesi'nden İşletme Bölümü Yönetim ve Organizasyon Dalı'ndan aldı (2010). Antalya Bilim Üniversitesi'nde çalışmaya başladı (2018) (Ayrıca Akdeniz Üniversitesi'nde ve çeşitli özel kurumlarda görev yaptı). Halen Antalya Bilim Üniversitesi Turizm Fakültesi'nde görev yapmaktadır. Temel çalışma alanları yönetim, girişimcilik, pazarlama, inovasyon ve sürdürülebilir turizmdir 